\section{(2) OPEN ACCESS}

\title{
Diagnostic and therapeutic aspects of hemiplegic migraine
}

\author{
Vincenzo Di Stefano (D) , ${ }^{1}$ Marianna Gabriella Rispoli, ${ }^{2}$ Noemi Pellegrino, ${ }^{3}$ \\ Alessandro Graziosi, ${ }^{3}$ Eleonora Rotondo, ${ }^{3}$ Christian Napoli, ${ }^{4}$ Daniela Pietrobon,, 6 \\ Filippo Brighina, ${ }^{1}$ Pasquale Parisi (iD ${ }^{7}$
}

1 Department of Biomedicine, Neuroscience and Advanced Diagnostic (BIND), University of Palermo, Palermo, Sicilia, Italy 2Department of Neuroscience Imaging and Clinical Sciences, 'G. d'Annunzio' University, Universita degli Studi Gabriele d'Annunzio Chieti e Pescara, Chieti Scalo, Chieti, Italy

${ }^{3}$ Pediatrics, University Gabriele d'Annunzio of Chieti Pescara Department of Medicine and Aging Science, Chieti, Abruzzo, Italy

${ }^{4}$ Department of Medical Surgical Sciences and Translational Medicine, Sapienza University of Rome, Roma, Lazio, Italy ${ }^{5}$ Department of Biomedical Sciences \& Padova Neuroscience Center, University of Padova, Padova, Italy

${ }^{6}$ CNR Neuroscience Institute, Padova, Italy

${ }^{7}$ Dipartimento di Neuroscienze Salute Mentale e Organi di Senso (NESMOS), University of Rome La Sapienza Faculty of Medicine and Psychology, Roma, Lazio, Italy

\section{Correspondence to}

Professor Pasquale Parisi, Dipartimento di Neuroscienze Salute Mentale e Organi di Senso (NESMOS), University of Rome La Sapienza Faculty of Medicine and Psychology, Roma 00189, Lazio, Italy; pasquale. parisi@uniroma1.it

Received 21 January 2020 Revised 22 April 2020 Accepted 24 April 2020 Published Online First 19 May 2020

\section{Check for updates}

(c) Author(s) (or their employer(s)) 2020. Re-use permitted under CC BY-NC. No commercial re-use. See rights and permissions. Published by BMJ.

To cite: Di Stefano $V$, Rispoli MG, Pellegrino N, et al. J Neurol Neurosurg Psychiatry 2020:91:764-771.

\section{ABSTRACT}

Hemiplegic migraine (HM) is a clinically and genetically heterogeneous condition with attacks of headache and motor weakness which may be associated with impaired consciousness, cerebellar ataxia and intellectual disability. Motor symptoms usually last $<72$ hours and are associated with visual or sensory manifestations, speech impairment or brainstem aura. HM can occur as a sporadic HM or familiar HM with an autosomal dominant mode of inheritance. Mutations in CACNA1A, ATP1A2 and SCN1A encoding proteins involved in ion transport are implicated. The pathophysiology of HM is close to the process of typical migraine with aura, but appearing with a lower threshold and more severity. We reviewed epidemiology, clinical presentation, diagnostic assessment, differential diagnosis and treatment of HM to offer the best evidence of this rare condition. The differential diagnosis of HM is broad, including other types of migraine and any condition that can cause transitory neurological signs and symptoms. Neuroimaging, cerebrospinal fluid analysis and electroencephalography are useful, but the diagnosis is clinical with a genetic confirmation. The management relies on the control of triggering factors and even hospitalisation in case of long-lasting auras. As HM is a rare condition, there are no randomised controlled trials, but the evidence for the treatment comes from small studies.

\section{INTRODUCTION}

Hemiplegic migraine (HM) is an uncommon subtype of migraine with aura that usually starts in the first or second decade of life. ${ }^{1}$ It is a clinically and genetically heterogeneous condition that represents a challenge for the clinician because it can occur with a dramatic and crippling clinical situation, resembling other more severe neurological diseases (ie, stroke). ${ }^{12}$

HM can occur as a sporadic or familial condition if at least one first-degree or second-degree relative has the same form of migraine. ${ }^{3}$ Familial hemiplegic migraine (FHM) is the only migraine form for which an autosomal dominant mode of inheritance has been documented. Genetic studies have demonstrated the involvement of at least three distinct genes that encode proteins involved in ion transport (CACNA1A, ATP1A2 and SCN1A). ${ }^{2}$ Mutation of those genes explains for about $7 \%-14 \%$ of FHM in two population studies. ${ }^{45}$ Some authors have hypothesised a role for gene PRRT2 in migraine pathophysiology, but its specific implication in HM is still debated. Given the lack of a recognised fourth autosomal dominant gene for FHM, other genetic mechanisms might be supposed and further genetic analyses are needed. ${ }^{2}$ Sporadic hemiplegic migraine (SHM) shares similar clinical characteristics with FHM but it differs for the absence of family history for HM. ${ }^{6}$

As $\mathrm{HM}$ is a rare condition, few studies are reported and there are no specific treatments. In this review, we will discuss in detail about epidemiology, clinical presentation, diagnostic assessment, differential diagnosis and treatment of this complex disorder.

\section{Epidemiology}

Although migraine is a common condition with a prevalence between $15 \%$ and $20 \%$ in the general population, HM is rare. The onset is generally in adolescence between 12 and 17 years $^{1478}$ and the overall estimated prevalence is $0.01 \% .{ }^{9}$ Females are more frequently affected, with a variable female/ male ratio among $2.5: 1$ and $4.3: 1 .^{9}{ }^{10}$ The frequency and severity of attacks progressively decrease with increasing age. ${ }^{1}$

\section{Clinical manifestations}

$\mathrm{HM}$ is characterised by recurrent attacks with headache and aura manifestations. Emotional and intense physical stress, viral infections and head trauma are the more common reported trigger factors for HM attacks. ${ }^{11} 12$ Table 1 describes diagnostic criteria for HM, according to the definition of the third edition of International Classification of Headache Disorders. ${ }^{3}$

Headache is almost always present during attacks and it is often severe. The localisation of headache is variable: bilateral, unilateral, ipsilateral or contralateral to the motor symptoms. ${ }^{1}$

Associated symptoms in $\mathrm{HM}$ can be distinguished in aura symptoms that occur during attacks and chronic symptoms that can be present interictally.

\section{Aura symptoms}

Unilateral weakness is always present during HM attacks and it is considered the most important sign; weakness can rarely be bilateral and sometimes it may switch side. Besides motor weakness, sensory symptoms (such as tingling, numbness and paraesthesia), visual defects (scintillating scotoma, 
Table 1 Diagnostic criteria of hemiplegic migraine

\begin{tabular}{|c|c|}
\hline & Diagnostic criteria ICHD-3 \\
\hline Hemiplegic migraine & $\begin{array}{l}\text { A. At least two attacks fulfilling criteria } \\
\text { B. One or more of the following fully reversible aurasymptoms: } \\
\text { 1. visual } \\
\text { 2. sensory } \\
\text { 3. speech and/or language } \\
\text { 4. motor } \\
\text { 5. brainstem } \\
\text { 6. retinal } \\
\text { C. At least three of the following six characteristics: } \\
\text { 1. at least one aura symptom spreads graduallyover } 5 \text { minutes } \\
\text { 2. two or more aura symptoms occur in succession } \\
\text { 3. each individual aura symptom lasts } 5-60 \text { minutes } \\
\text { 4. at least one aura symptom is unilateral } \\
\text { 5. at least one aura symptom is positive } \\
\text { 6. the aura is accompanied, or followed within } 60 \text { min, by headache } \\
\text { D. Aura consisting of both of the following: } \\
\text { 1. fully reversible motor weakness } \\
\text { 2. fully reversible visual, sensory and/or speech/ language symptoms. }\end{array}$ \\
\hline Familial hemiplegic migraine (FHM) & $\begin{array}{l}\text { A. Attacks fulfilling criteria for Hemiplegic migraine } \\
\text { B. At least one first- or second-degree relative has had attacks fulfilling criteria for Hemiplegic migraine. }\end{array}$ \\
\hline Familial hemiplegic migraine type 1 (FHM1) & $\begin{array}{l}\text { A. Attacks fulfilling criteria for Familial hemiplegic migraine } \\
\text { B. A mutation on the CACNA1A gene has been demonstrated. }\end{array}$ \\
\hline Familial hemiplegic migraine type 2 (FHM2) & $\begin{array}{l}\text { A. Attacks fulfilling criteria for Familial hemiplegic migraine } \\
\text { B. A mutation on the ATP1A2 gene has been demonstrated. }\end{array}$ \\
\hline Familial hemiplegic migraine type 3 (FHM3) & $\begin{array}{l}\text { A. Attacks fulfilling criteria for Familial hemiplegic migraine } \\
\text { B. A mutation on the SCN1A gene has been demonstrated. }\end{array}$ \\
\hline Familial hemiplegic migraine, other loci & $\begin{array}{l}\text { A. Attacks fulfilling criteria for Familial hemiplegic migraine } \\
\text { B. Genetic testing has demonstrated no mutation onthe CACNA1A, ATP1A2 or SCN1A genes. }\end{array}$ \\
\hline Sporadic hemiplegic migraine (SHM) & $\begin{array}{l}\text { A. Attacks fulfilling criteria for Hemiplegic migraine } \\
\text { B. No first- or second-degree relative fulfils criteriafor Hemiplegic migraine. }\end{array}$ \\
\hline
\end{tabular}

ICHD-3, third edition of International Classification of Headache Disorders.

hemianopia) and aphasia are the most frequent aura symptoms. Sometimes, migraine attacks may include other signs and symptoms such as fever, seizure, bilateral visual disturbances, a 'brainstem aura' with vertigo, dysarthria, ataxia, hyperacusia, tinnitus, impaired consciousness and even, in the worse conditions, coma. ${ }^{141013}$

The duration of symptoms is usually $20-60 \mathrm{~min}$ but, in some cases, the aura and motor deficit may onset quickly and simulate an ischaemic attack. ${ }^{8}$ The complete recovery from attacks is the rule, but in severe migraine attacks, hemiplegia and altered consciousness may persist for weeks until total recovery. ${ }^{14-17}$ There are cases of irreversible brain injury with cerebral atrophy, infarction, cognitive deficit and death secondary to severe HM attacks in cases with CACNA1A mutations. ${ }^{7}$

\section{Chronic symptoms}

Chronic symptoms can develop interictally in patients with HM and they usually depend on the specific gene involved. Indeed, cerebellar involvement with a gaze-evoked nystagmus and progressive ataxia has been associated with in FHM type 1 (FHM1) in about 60\% of cases, but is rare in FHM type 2 (FHM2). ${ }^{181819}$ Moreover, some mutations of CACNA1A or ATP1A2 have been associated with mental retardation and cognitive impairment after severe and recurrent episodes ${ }^{20-23}$; early onset attacks, coma and seizure are considered the main risk factors for this kind of complication. ${ }^{124}$ More recently, 50\% of children (aged 3-18 years) with a pathogenic CACNA1A mutation associated with $\mathrm{HM}$ and other benign paroxysmal events (torticollis, vertigo or tonic upgaze) showed an heterogeneous cognitive dysfunction without a specific cognitive profile, mainly associated with vermian cerebellar atrophy for these early onset CACNA1A-associated phenotype was proposed a classification as 'neurodevelopmental disorders', suggesting thus a close follow-up of psychomotor development and academic performances. $^{25}$

Seizures in HM may be partial or generalised, with or without fever. $^{26}$ Generally, the onset of epilepsy is in childhood and sometimes it happens before the first HM attack. Hopefully, seizures in patients with HM have a benign evolution ${ }^{1}$ and higher rates have been reported in families with FHM2. ${ }^{22}$ Of note, in patients with HM, epileptic fits are independent of migraine attacks. $^{727}$ Neurological evaluation during a migraine attack can show unilateral hyperreflexia and further sensorimotor signs affecting mostly the upper limbs. ${ }^{4} 2$

\section{Genetics}

FHM shows an autosomal dominant pattern of inheritance with $70 \%-90 \%$ penetrance. ${ }^{30}$ To date, linkage studies and mutational screening in FHM families have found three main causative genes-CACNA1A, ATP1A2 and SCN1A-which encode for ion transporters. FHM can be classified as FHM1 (MIM \#141500), FHM2 (MIM \#602481) or FHM3 (MIM \#609634) according to mutations in CACNA1A, ATP1A2 or SCN1A, respectively. ${ }^{130}$ Individuals with mutations in the same gene, or even family members with the same mutation, can show wide variability in clinical presentation. ${ }^{31}$ This suggests that unknown genetic or environmental factors can influence phenotype. ${ }^{30} 32$

SHM is diagnosed when there is no family history of HM. SHM can be caused by de novo mutations in the FHM genes. ${ }^{1}$ Early onset and presence of associated neurological symptoms increase the probability of finding an FHM mutation in sporadic cases. $^{2} 32$ In a Danish population-based study of SHM, the 
majority of patients $(92 / 100)$ did not show a mutation in the FHM genes. ${ }^{33}$ In a Finnish sample of patients with HM, none of the 201 studied patients with SHM had exonic mutations in the FHM genes. ${ }^{5}$ However, clinical similarities between FHM and SHM suggest that SHM is very likely to be a genetic disorder. So that, SHM could probably be caused by mutations in still unknown specific genes. ${ }^{1}$ Another possible explanation is that complex polygenic interaction of multiple gene variants with small size effects may occur in SHM, like in common migraine phenotypes. $^{2}$ Similar pathogenic mechanisms may also play a role in patients with FHM without confirmed mutations in FHM genes. $^{2}$

CACNA1A gene is localised on chromosome $19 \mathrm{p} 13$. It encodes the pore-forming a1 subunit of the neuronal voltagegated Cav2.1 channel, predominantly localised at the presynaptic terminals in the central nervous system. ${ }^{30}$ More than 30 FHM1 mutations have been identified in familial and sporadic cases. ${ }^{1}$ The majority are missense variants in functional domains of the calcium channel, but also deletions have been reported. ${ }^{34}$ These mutations result in gain-of-function effects, with increased $\mathrm{Ca}^{2+}$ influxand enhanced glutamate release (but unaltered GABA release) at cortical synapses. ${ }^{35}$ The consequence is an altered excitatory-inhibitory balance and increased susceptibility to cortical spreading depression (CSD) ${ }^{35-37}$ Besides FHM1, CACNA1A mutations can also be found in episodic ataxia type 2 (EA2; MIM \# 108500) and spinocerebellar ataxia type 6 (SCA 6; MIM \#183086). Clinical overlap among the three diseases has been reported. ${ }^{30}$ However, EA2 mutations can be missense, truncating or cause aberrant splicing of CACNA1A, usually leading to loss-of-function and decreased $\mathrm{Ca}^{2+}$ influx. On the other side, SCA6 mutations are usually small expansions of a polyglutamine in the C-terminal of the gene, which are responsible for accumulation of mutant Cav2.1 channels and selective degeneration of Purkinje cells. $^{30}$

ATP1A2 gene is localised on chromosome 1q23.2. It encodes the a2 subunit of the glial sodium-potassium ATPase pump. ${ }^{1}$ More than 80 causal variants have been linked to FHM2. Most are missense mutations localised in the catalytic $\mathrm{P}$ domain, the transmembrane domain or in the central region between them. ${ }^{30}$ The spectrum of FHM2 mutations also includes some deletions and an exonic duplication found in a patient with SHM phenotype. ${ }^{38}$ Functional studies have demonstrated that FHM2 mutations can either alter pump sensitivity to potassium, reduce the sodium/potassium turnover or generate non-functional proteins, ${ }^{22}$ leading to impaired glial reuptake of potassium and glutamate from the synaptic cleft and consequently increased the propensity to CSD. ${ }^{39} 40$

SCN1A gene is localised on chromosome 2q24.3. It encodes the pore-forming a1 subunit of the neuronal voltage-gated sodium channel Nav1.1, which regulates sodium permeability on GABAergic interneurons. Patients with SCN1A mutations can have pure HM or associated neurological disorders like generalised tonic-clonic epilepsy, elicited repetitive transient daily blindness or childhood epilepsy. ${ }^{30}$ FHM3 mutations are usually missense. ${ }^{41}$ In contrast with the folding-defective epileptogenic NaV1.1 mutations which showed loss of function also when rescued, ${ }^{42}$ FHM3 mutations (including a folding-defective mutation) provoke gain of function of NaV1.1 channels and hyperexcitability of GABAergic neurons. ${ }^{43}$ The increase of extracellular potassium concentration consequent to the increased firing of GABAergic interneurons has been proposed as a possible mechanism underlying increased propensity to CSD in FHM3. ${ }^{44}$

Searching for other potential HM genes, PRRT2 has been suggested as the fourth HM gene. ${ }^{45} 46$ It encodes a presynaptic transmembrane protein which is involved in synaptic vesicles fusion and regulation of voltage-gated calcium channel in glutamatergic neurons. Truncating mutation is the most common in PRRT2-related conditions. ${ }^{30}$ This gene is associated with paroxysmal kinesigenic dyskinesia and childhood epilepsy/seizure disorders. HM has been reported in a few PRRT2 mutation carriers with a 'typical PRRT2 phenotype'. ${ }^{47}$ PRRT2 variants show a low-penetrance mode of co-segregation. It is possible that PRRT2 gene acts as a disease modifier gene in HM with a complex polygenic mechanism. ${ }^{47}$

Rarely, mutations in PNKD, SLC2A1, SLC1A3 and SLC4A4 genes have been reported in patients with HM phenotype. ${ }^{30} 48-51$ All these variants might in principle disrupt excitatory-inhibitory balance and induce CSD. ${ }^{303752}$

\section{Diagnosis}

The diagnosis of HM lies in obtaining a detailed clinical history and excluding other possible causes for the patient's symptoms. There are no pathognomonic clinical, laboratory or radiological findings to diagnose HM.

Use of electroencephalography can show asymmetric slowwave activity with delta/theta waves in the hemisphere contralateral to the hemiparesis. ${ }^{12} 315354$

The cerebrospinal fluid (CSF) analysis may reveal increased protein concentration related to blood-brain barrier (BBB) dysfunction, ${ }^{38}$ but pleocytosis has also been reported. ${ }^{20}$

Little is known about imaging abnormalities in HM due to its rarity. Imaging studies between attacks are normal, except in patients with FHM1 or SHM1 with cerebellar atrophy. ${ }^{1}$ Swelling and/or cortical hyperintensity of the affected hemisphere have been described on T2/FLAIR-weighted MRI images performed during attacks. ${ }^{54-56}$ Some patients present mild gadolinium enhancement on brain MRIs, probably due to an alteration in the $\mathrm{BBB} .{ }^{57}$ It is also possible to find a reversible decrease in water diffusion, due to cytotoxic oedema. ${ }^{53}$ Abnormalities are contralateral to the motor weakness and tend to disappear after neurological deficits resolution. ${ }^{536}$ To note, these abnormalities may not be viewed if MRI is performed in the very beginning after onset of symptoms. ${ }^{54}$

\section{Differential diagnosis}

The differential diagnosis of HM is broad and includes other forms of migraine, as well as any condition that can cause transitory neurological signs and symptoms, cerebrovascular diseases, epilepsy with hemiparesis, infectious or inflammatory disease and tumour. ${ }^{6}$ Table 2 summarises the most frequent differential diagnoses, underlining the principal diagnostic clues and the prevalence of the considered disorders. Given the complexity of the differential diagnosis, it is imperative to approach to $\mathrm{HM}$ as a diagnosis of exclusion from more common conditions that may cause weakness and headache. Moreover, the difficulty in diagnosis is influenced by the frequency and duration of the attacks. In fact, many investigations are required in the event of a first episode, especially in patients with prolonged aura. ${ }^{58}$

Migraine with aura is the third most common stroke-mimic, following seizures and psychiatric disorders; it is responsible for about $18 \%$ of all improper thrombolytic treatments. ${ }^{59}$ When a patient presents with a motor deficit, it is more likely a secondary headache (ischaemic or haemorrhagic stroke) than a primary headache disorder. ${ }^{60}$ However, it is more challenging to differentiate HM from a transient ischaemic attack (TIA), as both are fully reversible and the neuroimaging is often unrevealing. Indeed, it has been reported in a minority of patients 
Table 2 Differential diagnoses in hemiplegic migraine

\begin{tabular}{|c|c|c|c|}
\hline Differential diagnosis & Main features & Clue for differential & Examinations required \\
\hline $\begin{array}{l}\text { Cerebrovascular disease (ie, transient } \\
\text { ischaemic attack (TIA) and ischaemic or } \\
\text { haemorrhagic stroke) }\end{array}$ & Sudden onset of neurological deficits & $\begin{array}{l}\text { Sudden onset (TIA and stroke) vs } \\
\text { gradual progressive spread (HM). } \\
\text { Prevalence of negative symptoms in } \\
\text { TIAs and strokes. } \\
\text { Timing of the headache: after motor } \\
\text { symptoms in HM and before them in } \\
\text { haemorrhagic strokes. }\end{array}$ & $\begin{array}{l}\mathrm{CT}, \mathrm{MRI} \text {, carotid ultrasound, transthoracic } \\
\text { echocardiogram, special coagulation profiles, } \\
\text { antiphospholipid antibody panel. }\end{array}$ \\
\hline $\begin{array}{l}\text { Cerebral amyloid angiopathy, even in } \\
\text { absence of bleeding }\end{array}$ & $\begin{array}{l}\text { Transient episodes of focal neurological } \\
\text { deficits known as amyloid spells }\end{array}$ & $\begin{array}{l}\text { Recurrent and stereotyped episodes } \\
\text { of paraesthesias, focal weakness or } \\
\text { dysphasia, usually lasting several } \\
\text { minutes. } \\
\text { Cortical superficial siderosis and } \\
\text { microbleeds on brain MRI. }\end{array}$ & MRI including blood-sensitive sequences. \\
\hline Epilepsy with hemiparesis & $\begin{array}{l}\text { Limb jerking, head-turning and loss of } \\
\text { consciousness at seizure onset }\end{array}$ & $\begin{array}{l}\text { Prolonged migratory progression of aura } \\
\text { over } 30 \mathrm{~min} \text { to hours vs short duration of } \\
\text { seizures (sudden and usually }<1 \mathrm{~min} \text { ). }\end{array}$ & Electroencephalogram, MRI. \\
\hline Brain tumours & $\begin{array}{l}\text { Progressive neurological symptoms; } \\
\text { neuroimaging and pathological } \\
\text { examination are required }\end{array}$ & $\begin{array}{l}\text { Precipitation of headache over } \\
\text { Valsalva manoeuvre and bending } \\
\text { over. } \\
\text { Headache is typical occipital or } \\
\text { frontal. }\end{array}$ & $\mathrm{CT}, \mathrm{MRI}$, proton MR spectroscopy. \\
\hline $\begin{array}{l}\text { Stroke-like migraine attacks after } \\
\text { radiation therapy }\end{array}$ & History of radiation therapy & $\begin{array}{l}\text { Typical neuroimaging features (thick } \\
\text { cortical gyral enhancement). } \\
\text { History of remote irradiation (even } \\
\text { after } 20-30 \text { years). }\end{array}$ & MRI with contrast. \\
\hline $\begin{array}{l}\text { Transient headache with neurological } \\
\text { deficits and cerebrospinal fluid } \\
\text { lymphocytosis (HaNDL) }\end{array}$ & Spinal fluid lymphocytosis & $\begin{array}{l}\text { Viral-like premonitory symptoms } \\
\text { before one-third of HaNDL attacks. } \\
\text { Monophasic course, with resolution } \\
\text { in } 3 \text { months. } \\
\text { - Rare visual symptoms in HaNDL. }\end{array}$ & MRI, CSF examination. \\
\hline Alternating hemiplegia of childhood & $\begin{array}{l}\text { Dystonia, epilepsy and cognitive } \\
\text { impairment }\end{array}$ & $\begin{array}{l}\text { Onset before } 18 \text { months. } \\
\text { Paroxysmal spells of hemiplegia, } \\
\text { quadriplegia, choreoathetotic } \\
\text { movements and nystagmus that } \\
\text { disappear immediately after sleep. } \\
\text { Attacks may resume soon after } \\
\text { awakening. }\end{array}$ & $\begin{array}{l}\text { CT or MRI, electroencephalogram (preferably } \\
\text { prolonged in order to capture an episode), } \\
\text { ATP1A3 gene sequencing. }\end{array}$ \\
\hline Central nervous system infections & $\begin{array}{l}\text { Cerebrospinal fluid analysis and } \\
\text { neuroimaging consistent with infection }\end{array}$ & $\begin{array}{l}\text { Presence of systemic symptoms (in } \\
\text { particular fever), nuchal rigidity and a } \\
\text { variety of psychiatric and behavioural } \\
\text { disturbances (ie, hallucinations and } \\
\text { psychosis). }\end{array}$ & $\begin{array}{l}\text { Complete blood count, erythrocyte } \\
\text { sedimentation rate, CSF examination, MRI. }\end{array}$ \\
\hline $\begin{array}{l}\text { Hereditary and metabolic disorders } \\
\text { (MELAS, CADASIL, hereditary } \\
\text { haemorrhagic telangiectasias) }\end{array}$ & $\begin{array}{l}\text { Characteristic genetic mutations, lactate } \\
\text { elevation, maternal or autosomal } \\
\text { inheritance }\end{array}$ & $\begin{array}{l}\text { Typical findings in MELAS: episodes } \\
\text { of migrainous headache, stroke-like } \\
\text { focal deficits, increased lactate in } \\
\text { serum and CSF during the attack, } \\
\text { MRI abnormalities, especially in the } \\
\text { posterior cerebral cortex. } \\
\text { Cognitive impairment and sudden- } \\
\text { onset focal neurological deficits are } \\
\text { associated with CADASIL. }\end{array}$ & $\begin{array}{l}\text { Lactate, CSF examination, electroencephalogram, } \\
\text { CT and/or MRI, muscle biopsy, genetic testing. }\end{array}$ \\
\hline
\end{tabular}

CADASIL, cerebral autosomal dominant arteriopathy with subcortical infarcts and leukoencephalopathy; HM, hemiplegic migraine; MELAS, mitochondrial myopathy, encephalopathy, lactic acidosis and stroke-like episodes syndrome.

that $\mathrm{HM}$ attacks can have an abrupt onset and, if the duration of the attack is enough prolonged, clinicians may misdiagnose patients having a TIA, especially in the presence of risk factor for ischaemic stroke. We previously described the case of a patient with late-onset SHM (missense mutation of the ATP1A2 gene) with hypertension and severe carotid stenoses. ${ }^{21}$ Conversely, recurrent TIAs can be evocative of SHM in patients with rare syndromes who fulfil criteria for HM. ${ }^{61}$ Nevertheless, TIAs and strokes have a sudden onset, while HM typically shows gradual progressive spread with aura ${ }^{1}$; the neuroimaging can be helpful to distinguish among these conditions, but the timing of the headache also provides relevant information, because the headache usually follows the motor weakness in HM and precedes the weakness in haemorrhagic strokes. ${ }^{59}$ In addition, headache is common in haemorrhagic stroke, but it is rare in TIAs, and HM occurs more frequently in young people. ${ }^{59}$

The differential diagnosis of $\mathrm{HM}$ also includes hereditary cerebral angiopathies. ${ }^{162}$ Cerebral autosomal dominant arteriopathy with subcortical infarcts (CADASIL) is the most common cause of inherited stroke in adults ${ }^{163}$ and is caused by mutations of the $\mathrm{NOTCH} 3$ gene on chromosome $19 .{ }^{64}$ As for HM, migraine with aura can be the initial symptom in CADASIL; gradual motor symptoms can be present in CADASIL patients who have attacks of migraine with aura. Motor aura in HM usually starts in the 


\begin{tabular}{|c|c|c|c|c|}
\hline Drug & Mechanism of action & Administration & Clinical outcome & Level of evidence \\
\hline \multicolumn{5}{|l|}{ Acute management of aura } \\
\hline Verapamil & $\begin{array}{l}\text { Calcium antagonism on L-type calcium } \\
\text { channel, blocking calcium influx and reducing } \\
\text { vasoconstriction. } \\
\text { Less prominent effects on P/Q calcium channels. }\end{array}$ & $\begin{array}{l}\text { Intravenous verapamil ( } 5 \mathrm{mg} \text { over } 5 \mathrm{~min}) \text {, } \\
\text { followed by an oral maintenance dose of } \\
120 \mathrm{mg} / \text { day. }\end{array}$ & $\begin{array}{l}\text { Significative reduction of headache, but not } \\
\text { completely resolution of hemiplegia, especially in } \\
\text { patients with CACNA1A mutations. }\end{array}$ & $\begin{array}{l}\text { Low; case reports and small studies } \\
\left.\text { (Yu et } a l^{94}\right) \text {. }\end{array}$ \\
\hline Ketamine & NMDA glutamate receptors antagonism. & Intranasal administration. & May be beneficial in about $45 \%$ of cases. & $\begin{array}{l}\text { Low; a study on } 11 \text { patients with FHM } \\
\text { (Kaube et } a^{82} \text { ). }\end{array}$ \\
\hline Triptans & -5- $\mathrm{HT}_{1 \mathrm{~B} / \mathrm{D}}$ agonism. & Oral or subcutaneous. & $\begin{array}{l}\text { In a study on } 76 \text { patients with } \mathrm{HM}, 62 \% \text { reported } \\
\text { a good or excellent response with moderate } \\
\text { adverse events (chest pain, nausea and fatigue), }\end{array}$ & $\begin{array}{l}\text { Debated; the evidence comes from a } \\
\text { study of } 76 \text { patients with HM (Artto } \\
\text { et al }{ }^{91} \text { ). }\end{array}$ \\
\hline $\begin{array}{l}\text { Corticosteroid pulses } \\
\text { and hypertonic solution }\end{array}$ & $\begin{array}{l}\text { Steroids: } \\
\text { indirect inhibition of the activity of voltage- } \\
\text { dependent calcium channels; } \\
\text { reduction of CSD. } \\
\text { Hypertonic solution: } \\
\text { unknown. }\end{array}$ & $\begin{array}{l}\text { Intravenous dexamethasone } 0.5 \mathrm{mg} / \\
\mathrm{kg} / \text { day in three pulses/day for } 3 \text { days } \\
\text { followed by gradual oral tapering and } \\
\text { hypertonic solution at } 3 \% 1.5 \mathrm{~mL} / \mathrm{kg} / \mathrm{hour} \text {, } \\
\text { maintaining sodium between } 145 \text { and } \\
155 \mathrm{mEq} / \mathrm{L} \text {. In another report, a scheme } \\
\text { with a } 5 \text {-day treatment of } 100 \mathrm{mg} / \text { day } \\
\text { methylprednisolone was used. }\end{array}$ & $\begin{array}{l}\text { Rapid reduction in severity and duration of acute } \\
\text { attacks in the presence of encephalopathy and } \\
\text { cerebral oedema in patients with CACNA1A } \\
\text { mutations. }\end{array}$ & $\begin{array}{l}\text { Low; single reports (Sánchez-Albisua } \\
\text { et } a^{89} \text {; García Segarra et al }{ }^{100} \text {; Camia } \\
\text { et } a l^{97} \text { ). }\end{array}$ \\
\hline $\begin{array}{l}\text { Prochlorperazine and } \\
\text { magnesium sulfate }\end{array}$ & $\begin{array}{l}\text { Dopamine D2 receptors antagonism. } \\
\text { Blockage of CSD due to magnesium. }\end{array}$ & Intravenous. & $\begin{array}{l}\text { Intravenous prochlorperazine and magnesium } \\
\text { sulfate seemed to resolve prolonged migrainous } \\
\text { aura. }\end{array}$ & $\begin{array}{l}\text { Putative; little evidence based on a } \\
\text { single report (Rozen et } a^{88} \text { ). }\end{array}$ \\
\hline Naloxone & $\begin{array}{l}\text { Opiate-antagonism (possible role for } \\
\text { endorphins). }\end{array}$ & $0.4 \mathrm{mg}$ of intravenous naloxone. & $\begin{array}{l}\text { Aborted neurological sequelae in two patients } \\
\text { with SHM. }\end{array}$ & $\begin{array}{l}\text { Putative; little evidence based on a } \\
\text { single report (Centonze et }\left.a\right|^{98} \text { ). }\end{array}$ \\
\hline Furosemide & - Possible cessation of CSD. & Intravenous. & $\begin{array}{l}\text { Seemed to resolve prolonged migrainous aura in } \\
\text { two patients. }\end{array}$ & $\begin{array}{l}\text { Putative; little evidence based on a } \\
\left.\text { single report (Rozen et } a^{87}\right) \text {. }\end{array}$ \\
\hline \multicolumn{5}{|l|}{ Prophylactic treatment } \\
\hline Verapamil & $\begin{array}{l}\text { Calcium antagonism on L-type calcium } \\
\text { channel, blocking calcium influx and reducing } \\
\text { vasoconstriction. } \\
\text { - Less prominent effects on P/Q calcium channels. }\end{array}$ & $\begin{array}{l}\text { Oral verapamil ( } 120 \mathrm{mg} \text { twice or three times } \\
\text { in a day). }\end{array}$ & $\begin{array}{l}\text { May be effective in reducing the burden of } \\
\text { attacks in HM. }\end{array}$ & $\begin{array}{l}\text { Low; case reports and small studies } \\
\left(\text { Lai et } a l^{83} ; \text { Razavi et al } l^{86} ; \text { Yu et a } a^{95} ;\right. \\
\text { Lastimosa et a }\left.\right|^{85} ; \text { Hsu et a } a^{102} ; \text { Rispoli } \\
\left.\text { et } a l^{21}\right) \text {. }\end{array}$ \\
\hline Acetazolamide & $\begin{array}{l}\text { Unknown; a local } \mathrm{pH} \text { change around the P/Q } \\
\mathrm{Ca}^{2+} \text { channel may result in improved channel } \\
\text { functioning. }\end{array}$ & Oral $250-500 \mathrm{mg}$ twice a day. & $\begin{array}{l}\text { May be effective in reducing the burden of } \\
\text { attacks in HM and nystagmus, especially in } \\
\text { patients with CACNA1A mutations (EA2, SCA6) } \\
\text { and CADASIL. }\end{array}$ & $\begin{array}{l}\text { Low; little evidence based on case } \\
\text { reports and case series } \\
\left(\text { Athwal et } a l^{96} \text {; Battistini et } a l^{19} \text {; Striano }\right. \\
\text { et al }\left.\right|^{103} ; \text { Suzuki et } a l^{18} \text { ). }\end{array}$ \\
\hline Flunarizine & $\begin{array}{l}\text { Non-selective calcium ion channel and } \\
\text { dopamine receptor antagonism. } \\
\text { 5-HT and antihistamine receptors antagonism. }\end{array}$ & Oral $10 \mathrm{mg} /$ day. & $\begin{array}{l}\text { Generally effective and well-tolerated, except } \\
\text { for low rate of adverse effects (tiredness, mood } \\
\text { changes and weight gain). }\end{array}$ & $\begin{array}{l}\text { Low; single reports (Tobita et } a l^{90} \text {; } \\
\text { Karsan et } a l^{81} \text { ). }\end{array}$ \\
\hline Lamotrigine & $\begin{array}{l}\text { Blockage of the sodium channels, decreasing } \\
\text { the neuronal release of glutamate. }\end{array}$ & Oral. & May be beneficial. & $\begin{array}{l}\text { Low; a study with eight patients with } \\
\text { motor aura, a case report (Lampl et a } a^{\beta 4} \text {; } \\
\text { Camia et } a f^{97} \text { ). }\end{array}$ \\
\hline Propranolol & - Unknown. & $\begin{array}{l}\text { Oral } 10 \mathrm{mg} \mathrm{3-4} \mathrm{times} \mathrm{a} \mathrm{day} \mathrm{and} \\
\text { maintenance from } 1.5 \text { to } 3.0 \mathrm{mg} / \mathrm{kg} / \text { day. }\end{array}$ & $\begin{array}{l}\text { Effective in three patients with longer symptom- } \\
\text { free intervals. }\end{array}$ & Low; single report (Lai et $a^{\beta 3}{ }^{3}$ ) \\
\hline $\begin{array}{l}\text { Memantine and } \\
\text { dextromethorphan }\end{array}$ & - NMDA antagonism. & Oral. & $\begin{array}{l}\text { Significant improvement of behavioural, } \\
\text { cognitive and cerebellar symptoms in a patient } \\
\text { with ATP1A2 mutation. }\end{array}$ & Putative; single report (Ueda et $a^{92}$ ). \\
\hline Telcagepant & CGRP receptor antagonism. & Oral. & May be beneficial. & Putative (Ho et al $\left.{ }^{101}\right)$. \\
\hline Onabotulinumtoxin $\mathrm{A}$ & - Unknown. & Subcutaneous. & Reduction of aura frequency and severity. & $\begin{array}{l}\text { Putative; single report (Chen et } a^{99} \text {; } \\
\text { Young et } a l^{93} \text { ). }\end{array}$ \\
\hline Topiramate & - Unknown. & Oral. & $\begin{array}{l}\text { Worsening of symptoms in a single HM case: } \\
\text { dysphasia, disorientation, and prolonged severe } \\
\text { right-sided weakness complicating a migraine } \\
\text { attack lasting for about } 4 \text { days. }\end{array}$ & Putative; single report (Striano et $a l^{103}$ ). \\
\hline
\end{tabular}

CADASIL, cerebral autosomal dominant arteriopathy with subcortical infarcts and leukoencephalopathy; CGRP, calcitonin gene-related peptide; CSD, cortical spreading depression; HM, hemiplegic migraine; 5-HT, 5-hydroxy tryptamine; NMDA, $\mathrm{N}$-methyl-D-aspartate.

hand gradually spreading to the arm and face, while 'strokelike episodes' resembling the classic lacunar syndromes occur in CADASIL. Gradual motor symptoms resembling HM and acute stroke-like episodes may both fit the diagnosis of CADASIL; hence, the NOTCH3 genetic testing is warranted. Cognitive deficits, mood disorders and MRI alterations are more common in CADASIL. ${ }^{63}$ Amyloid spells have been recently described as transient episodes of neurological deficits occurring in patients with amyloid angiopathy even in absence of bleeding, arising a further differential for HM. ${ }^{65-67}$ In these cases, the diagnosis may escape on standard neuroimaging, but MRI is diagnostic revealing superficial siderosis and microbleeds. ${ }^{67}$

Epilepsy is often diagnosed incorrectly in children with HM. Seizures with postictal paralysis, specifically Todd's palsies can be confused with motor auras. ${ }^{12462}$ Unfortunately, up to $7 \%$ of patients with FHM develop epilepsy complicating the differential. ${ }^{2668}$ In HM the progression of the crisis is over 30 min to hours, while seizures are brief and usually last minutes; also, epilepsy with hemiparesis is usually characterised by limb jerking, head-turning and loss of consciousness at seizure onset. Brain tumours presenting with secondary epilepsy usually cause progressive neurological symptoms and they should be excluded by CT or MRI. ${ }^{6}$

The presence of the headache is a mainstay, but many conditions can present with headache and transient neurological deficits. As a consequence, migraine mimics are primary or secondary headache disorders with features in common with migraine $^{69}$; any condition that shows neurological deficits in the absence of radiological alterations should be considered. A careful history, followed by an accurate general and neurological examination looking for red flags that suggest the possibility of a secondary headache disorder or an underlying cause of hemiparesis are necessary. ${ }^{70}$

Central nervous system infections may also cause a clinical picture similar to HM with fever and impaired consciousness. CSF analysis and neuroimaging usually allow a clear distinction between the two conditions. ${ }^{71}$ 
The syndrome 'stroke-like migraine attacks after radiation therapy' may also mimic HM. The history of previous cerebral irradiation and the typical neuroimaging features (thick cortical gyral enhancement) usually allow an easy recognition. ${ }^{72}$ However, this condition often occurs even 20-30 years after cerebral irradiation making sometimes difficult to recall a history of irradiation. ${ }^{7374}$ Moreover, cortical gadolinium enhancement has been reported in HM. ${ }^{57}$ For these reasons, any history of previous cerebral irradiation should be searched.

Alternating hemiplegia of childhood is a very rare genetic condition, caused by mutations in the ATP1A3 gene and characterised by periodic episodes of hemiplegia or quadriplegia. Associated features including dystonia, epilepsy and cognitive impairment help the clinician to make the correct diagnosis. ${ }^{75}$

Headache with neurological deficits and CFS lymphocytosis (HaNDL) is a rare sporadic condition that can present with episodic headache, hemiparesis and aphasia, and may have regional blood flow abnormalities during the ictal phase. The diagnosis requires spinal fluid lymphocytosis. ${ }^{76} 77$ Of interest, there are described cases of patients with FHM1 presenting CSF pleocytosis. ${ }^{20}$ However, HaNDL is monophasic with resolution in 3 months, while $\mathrm{HM}$ recur for decades ${ }^{62}$; also, only a minority of attacks of HaNDL include visual symptoms, while visual aura is very common in HM. ${ }^{1176}$

Various inflammatory or metabolic disorders should be considered in the differential diagnosis of HM as well as some mitochondrial diseases. ${ }^{78}$ These conditions, including recurrent migraine-like headaches and neurological deficits, are distinguished based on their clinical, neuroimaging and genetic features. ${ }^{79}$ Finally, Sturge-Weber disease (which can be easily differentiated for the peculiar cutaneous features) has recently been considered as possible cause of apparently isolated HM. ${ }^{80}$

\section{Treatment}

As there are no randomised controlled trials in patients with HM, the treatment remains empirical, similarly to the more common types of migraine, based on small studies and single reports. ${ }^{20} 2180-103$

The management of HM relies on the control of triggering factors and sometimes severe attacks can require hospitalisation to ensure fluid balance and food intake. Fever and seizures can be treated symptomatically. ${ }^{158}$ There are reports of exacerbations due to vasoconstrictive drugs (ergotamine and dihydroergotamine) in patients with HM, raising the concern that vasoconstriction might aggravate the aura. ${ }^{58}$ As a consequence, the use of triptans is debated and they are historically contraindicated; hence patients with HM have been excluded from clinical trials. ${ }^{1}$ In a retrospective study, triptans appeared to be effective in the treatment of headache; of interest, about half of patients preferred to use triptans during aura as opposed to patients with migraine with aura. ${ }^{91}$ Finally, in a single case, a woman affected by $\mathrm{HM}$ worsened after starting prophylactic treatment with topiramate. ${ }^{103}$ Hence, a medication that can abolish the longlasting and bothersome aura symptoms is in demand. Many authors support the idea that the propagation of CSD, mediated by the release of glutamate and activation of NMDA receptors, may be the correct target for the acute management of the aura. According to this theory, any medications that inhibit CSD might be useful in the treatment of aura. Nasal administration of ketamine reduced the duration of the aura in patients with FHM. ${ }^{82}$ Furosemide and magnesium exploit a similar mechanism acting in CSD. ${ }^{87} 88$ Moreover, intravenous verapamil has shown to be effective for the recovery of both headache and aura in three out of four patients with HM in a single report. ${ }^{95}$ Moreover, a prompt recovery has been described in three patients with CACNA1A mutations through the combined use of steroids and hypertonic solutions in course of encephalopathy and cerebral oedema. ${ }^{89} 97100$ However, the current evidence is still based on single reports or studies on a small cohort of patients, often lacking a confirmed genetic diagnosis of HM.

Current therapeutic recommendations are based on isolated reports and suggest a possible prophylactic treatment with verapamil and acetazolamide to reduce frequency and severity of migraine attacks, but many new agents have been proposed $^{7} 20216380-103$ (table 3).

\section{CONCLUSIONS}

HM is a complex monogenic disorder related to a mutation in genes encoding for ion transporters. However, our knowledge on the pathophysiology of $\mathrm{HM}$ is evolving with new insights coming from the last 2 years. ${ }^{2} 51121252630313444525468929399$

The diagnosis of HM is moreover clinical, but genetic testing is necessary to find out the genetic subtype; neuroimaging with MRI and neurophysiology techniques have an important role in the differential diagnosis from conditions that might cause transient neurological deficits, mimicking an attack of HM.

There is a little evidence for agents for the acute setting during attacks and prophylactic treatment with verapamil and acetazolamide to reduce frequency and severity of migraine attacks. Abortive treatments are quite effective when started early from disease onset; however, the current therapeutic recommendations are based on isolated reports but there is no adequate evidence due to the lack of controlled trials. Hence, a medication that can abolish the long-lasting and bothersome aura symptoms is in demand.

Furthermore, our understanding of pathophysiology in HM has improved in the last years. Recent advances have improved our understandings on the pathogenesis of HM. Several drugs might be candidates for possible use in clinical practice, but their efficacy and safety profiles have to be demonstrated.

Contributors All authors contributed to the study conception and design. VDS, MGR, NP, AG and ER did the literature search, data analysis and wrote the first draft of the manuscript. All authors commented on previous version of the manuscript. CN, DP, FB and PP revised the work. All authors read and approved the final manuscript.

Funding The authors have not declared a specific grant for this research from any funding agency in the public, commercial or not-for-profit sectors.

Competing interests None declared.

Patient consent for publication Not required.

Provenance and peer review Not commissioned; externally peer reviewed.

Open access This is an open access article distributed in accordance with the Creative Commons Attribution Non Commercial (CC BY-NC 4.0) license, which permits others to distribute, remix, adapt, build upon this work non-commercially, and license their derivative works on different terms, provided the original work is properly cited, appropriate credit is given, any changes made indicated, and the use is non-commercial. See: http://creativecommons.org/licenses/by-nc/4.0/.

\section{ORCID iDs}

Vincenzo Di Stefano http://orcid.org/0000-0001-9805-1655

Pasquale Parisi http://orcid.org/0000-0001-9042-8120

\section{REFERENCES}

1 Russell MB, Ducros A. Sporadic and familial hemiplegic migraine: pathophysiological mechanisms, clinical characteristics, diagnosis, and management. Lancet Neurol 2011;10:457-70

2 Pelzer N, Haan J, Stam AH, et al. Clinical spectrum of hemiplegic migraine and chances of finding a pathogenic mutation. Neurology 2018;90:e575-82.

3 Olesen J, Bendtsen L, Dodick D, et al. Headache classification Committee of the International headache Society (IHS) the International classification of headache disorders, 3rd edition. Cephalalgia 2018;38:1-211. 
4 Thomsen LL, Eriksen MK, Roemer SF, et al. A population-based study of familial hemiplegic migraine suggests revised diagnostic criteria. Brain 2002;125:1379-91.

5 Hiekkala ME, Vuola P, Artto V, et al. The contribution of CACNA1A, Atp1a2 and SCN1A mutations in hemiplegic migraine: a clinical and genetic study in Finnish migraine families. Cephalalgia 2018;38:1849-63.

6 Pelzer N, Stam AH, Haan J, et al. Familial and sporadic hemiplegic migraine: diagnosis and treatment. Curr Treat Options Neurol 2013;15:13-27.

7 Kumar A, Arora R. Headache, migraine hemiplegic, 2018. Available: http://www.ncbi. nlm.nih.gov/pubmed/30020674 [Accessed 16 Dec 2019].

8 Ducros A, Denier C, Joutel A, et al. The clinical spectrum of familial hemiplegic migraine associated with mutations in a neuronal calcium channel. N Eng/ J Med 2001:345:17-24.

9 Lykke Thomsen L, Kirchmann Eriksen M, Faerch Romer S, et al. An epidemiological survey of hemiplegic migraine. Cephalalgia 2002;22:361-75.

10 Thomsen LL, Ostergaard E, Olesen J, et al. Evidence for a separate type of migraine with aura: sporadic hemiplegic migraine. Neurology 2003;60:595-601.

11 Toldo I, Brunello F, Morao V, et al. First attack and clinical presentation of hemiplegic migraine in pediatric age: a multicenter retrospective study and literature review. Front Neurol 2019;10:1079.

12 Hansen JM, Hauge AW, Ashina M, et al. Trigger factors for familial hemiplegic migraine. Cephalalgia 2011;31:1274-81.

13 Haan J, Terwindt GM, Ophoff RA, et al. Is familial hemiplegic migraine a hereditary form of basilar migraine? Cephalalgia 1995;15:477-81.

14 Saleh C, Pierquin G, Beyenburg S. Hemiplegic migraine presenting with prolonged somnolence: a case report. Case Rep Neurol 2016;8:204-10.

15 Lai T-H, Hong C-T. Prolonged symptoms in sporadic hemiplegic migraine: aura or migrainous infarction? Acta Neurol Taiwan 2012;21:129-32.

16 Kumar G, Topper L, Maytal J. Familial hemiplegic migraine with prolonged aura and multimodality imaging: a case report. Headache 2009;49:139-42.

17 Toldo I, Cecchin D, Sartori S, et al. Multimodal neuroimaging in a child with sporadic hemiplegic migraine: a contribution to understanding pathogenesis. Cephalalgia 2011;31:751-6.

18 Suzuki M, Fujiwara K, Tsubuku T, et al. Time course of downbeat positioning nystagmus in familial hemiplegic migraine type 1 treated with acetazolamide. $J$ Neurol Sci 2016:368:206-8.

19 Battistini S, Stenirri S, Piatti M, et al. A new CACNA1A gene mutation in acetazolamide-responsive familial hemiplegic migraine and ataxia. Neurology 1999;53:38-43.

20 Vahedi K, Denier C, Ducros A, et al. Cacna1A gene de novo mutation causing hemiplegic migraine, coma, and cerebellar atrophy. Neurology 2000;55:1040-2.

21 Rispoli MG, Di Stefano V, Mantuano E, et al. Novel missense mutation in the Atp1a2 gene associated with atypical sporapedic hemiplegic migraine. BMJ Case Rep 2019;12. doi:10.1136/bcr-2019-231129. [Epub ahead of print: 05 Oct 2019].

22 Friedrich T, Tavraz NN, Junghans C. Atp1A2 mutations in migraine: seeing through the facets of an ion pump onto the neurobiology of disease. Front Physiol 2016;7:239.

23 Pelzer N, Blom DE, Stam AH, et al. Recurrent coma and fever in familial hemiplegic migraine type 2. A prospective 15-year follow-up of a large family with a novel Atp1a2 mutation. Cephalalgia 2017;37:737-55.

24 Lebas A, Guyant-Maréchal L, Hannequin D, et al. Severe attacks of familial hemiplegic migraine, childhood epilepsy and Atp1a2 mutation. Cephalalgia 2008;28:774-7.

25 Humbertclaude V, Riant F, Krams B, et al. Cognitive impairment in children with CACNA1A mutations. Dev Med Child Neurol 2020;62:330-7.

26 Prontera P, Sarchielli P, Caproni S, et al. Epilepsy in hemiplegic migraine: genetic mutations and clinical implications. Cephalalgia 2018;38:361-73.

27 Vanmolkot KRJ, Kors EE, Hottenga J-J, et al. Novel mutations in the Na+, K+-ATPase pump gene Atp1a2 associated with familial hemiplegic migraine and benign familial infantile convulsions. Ann Neurol 2003;54:360-6.

28 Terwindt GM, Ophoff RA, Lindhout D, et al. Partial cosegregation of familial hemiplegic migraine and a benign familial infantile epileptic syndrome. Epilepsia 1997;38:915-21.

29 Bradshaw P, Parsons M. Hemiplegic migraine, a clinical study. Q J Med 1965:34:65-85.

30 Sutherland HG, Albury CL, Griffiths LR. Advances in genetics of migraine. J Headache Pain 2019:20.

31 Angelini C, Van Gils J, Bigourdan A, et al. Major intra-familial phenotypic heterogeneity and incomplete penetrance due to a CACNA1A pathogenic variant. Eur J Med Genet 2019;62:103530.

32 Riant F, Ducros A, Ploton C, et al. De novo mutations in Atp 1a2 and CACNA1A are frequent in early-onset sporadic hemiplegic migraine. Neurology 2010;75:967-72.

33 Thomsen LL, Oestergaard E, Bjornsson A, et al. Screen for CACNA1A and Atp1a2 mutations in sporadic hemiplegic migraine patients. Cephalalgia 2008;28:914-21.

34 Grieco GS, Gagliardi S, Ricca I, et al. New CACNA1A deletions are associated to migraine phenotypes. J Headache Pain 2018;19:75.

35 Tottene A, Conti R, Fabbro A, et al. Enhanced excitatory transmission at cortical synapses as the basis for facilitated spreading depression in $\mathrm{Ca}(\mathrm{V}) 2.1$ knockin migraine mice. Neuron 2009;61:762-73.
36 van den Maagdenberg AMJM, Pietrobon D, Pizzorusso T, et al. A CACNA1A knockin migraine mouse model with increased susceptibility to cortical spreading depression. Neuron 2004;41:701-10

37 Vecchia D, Pietrobon D. Migraine: a disorder of brain excitatory-inhibitory balance? Trends Neurosci 2012;35:507-20.

38 Gagliardi S, Grieco GS, Gualandi F, et al. De novo exonic duplication of Atp1a2 in Italian patient with hemiplegic migraine: a case report. J Headache Pain 2017;18.

39 Capuani C, Melone M, Tottene A, et al. Defective glutamate and K+ clearance by cortical astrocytes in familial hemiplegic migraine type 2. EMBO Mol Med 2016;8:967-86.

40 Leo L, Gherardini L, Barone V, et al. Increased susceptibility to cortical spreading depression in the mouse model of familial hemiplegic migraine type 2. PLoS Genet 2011;7:e1002129

41 Dichgans M, Freilinger T, Eckstein G, et al. Mutation in the neuronal voltage-gated sodium channel SCN1A in familial hemiplegic migraine. Lancet 2005;366:371-7.

42 Bechi G, Rusconi R, Cestèle $S$, et al. Rescuable folding defective Nav1.1 (SCN1A) mutants in epilepsy: properties, occurrence, and novel rescuing strategy with peptides targeted to the endoplasmic reticulum. Neurobiol Dis 2015;75:100-14.

43 Cestèle S, Schiavon E, Rusconi R, et al. Nonfunctional Nav1.1 familial hemiplegic migraine mutant transformed into gain of function by partial rescue of folding defects. Proc Natl Acad Sci U S A 2013;110:17546-51.

44 Jansen NA, Dehghani A, Linssen MML, et al. First FHM3 mouse model shows spontaneous cortical spreading depolarizations. Ann Clin Transl Neurol 2020;7:132-8.

45 Ebrahimi-Fakhari D, Saffari A, Westenberger A, et al. The evolving spectrum of PRRT2-associated paroxysmal diseases. Brain 2015;138:3476-95.

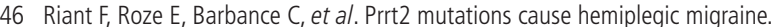
Neurology 2012;79:2122-4.

47 Pelzer N, de Vries B, Kamphorst JT, et al. Prrt2 and hemiplegic migraine: a complex association. Neurology 2014;83:288-90.

48 Jen JC, Wan J, Palos TP, et al. Mutation in the glutamate transporter EAAT1 causes episodic ataxia, hemiplegia, and seizures. Neurology 2005;65:529-34.

49 Suzuki M, Van Paesschen W, Stalmans I, et al. Defective membrane expression of the $\mathrm{Na}(+)-\mathrm{HCO}(3)(-)$ cotransporter NBCe1 is associated with familial migraine. Proc Natl Acad Sci U S A 2010;107:15963-8.

50 Mohammad SS, Coman D, Calvert S. Glucose transporter 1 deficiency syndrome and hemiplegic migraines as a dominant presenting clinical feature. J Paediatr Child Health 2014:50:1025-6.

51 Gardiner AR, Jaffer F, Dale RC, et al. The clinical and genetic heterogeneity of paroxysmal dyskinesias. Brain 2015;138:3567-80.

52 Pietrobon D, Brennan KC. Genetic mouse models of migraine. J Headache Pain 2019;20:79.

53 Jacob A, Mahavish K, Bowden A, et al. Imaging abnormalities in sporadic hemiplegic migraine on conventional MRI, diffusion and perfusion MRI and MRS. Cephalalgia 2006;26:1004-9.

54 Roth C, Ferbert A, Huegens-Penzel M, et al. Multimodal imaging findings during severe attacks of familial hemiplegic migraine type 2. J Neurol SCi 2018:392:22-7.

55 Bhatia H, Babtain F. Sporadic hemiplegic migraine with seizures and transient MRI abnormalities. Case Rep Neurol Med 2011;2011:1-4.

56 Sugrue $\mathrm{G}$, Bolster $\mathrm{F}$, Crosbie I, et al. Hemiplegic migraine: neuroimaging findings during a hemiplegic migraine attack. Headache 2014;54:716-8.

57 Cha Y-H, Millett D, Kane M, et al. Adult-Onset hemiplegic migraine with cortical enhancement and oedema. Cephalalgia 2007;27:1166-70.

58 Black DF. Sporadic and familial hemiplegic migraine: diagnosis and treatment. Semin Neurol 2006;26:208-16.

59 Terrin A, Toldo G, Ermani M, et al. When migraine mimics stroke: a systematic review. Cephalalgia 2018;38:2068-78.

60 Haraguchi K, Toyama K, Ito T, et al. A case of posterior cerebral artery dissection presenting with migraine-like headache and visual field defect: usefulness of fast imaging employing steady-state acquisition (FIESTA) for diagnosis. I Stroke Cerebrovasc Dis 2012;21:906.e5-7:906.e5-906.e7.

61 Di Stefano V, Colasurdo M, Onofrj M, et al. Recurrent stereotyped TIAs: atypical Bow Hunter's syndrome due to compression of non-dominant vertebral artery terminating in PICA. Neurol Sci 2020;2.

62 Black DF. Sporadic hemiplegic migraine. Curr Pain Headache Rep 2004;8:223-8.

63 Rossi G, Shambhu S. Hemiplegic migraine as the initial presentation of biopsy positive cerebral autosomal dominant arteriopathy with subcortical infarcts and leukoencephalopathy. Cureus 2018;10:e2631.

64 Joutel A, Corpechot C, Ducros A, et al. Notch3 mutations in CADASIL, a hereditary adult-onset condition causing stroke and dementia. Nature 1996:383:707-10.

65 Charidimou A, Law R, Werring DJ. Amyloid "spells" trouble. The Lancet 2012;380:1620.

66 Samanci B, Coban O, Baykan B. Late onset aura may herald cerebral amyloid angiopathy: a case report. Cephalalgia 2016;36:998-1001.

67 Coates R, Bell SM, Coley S, et al. Cerebral amyloid angiopathy: amyloid spells and cortical superficial siderosis. Pract Neurol 2015;15:124-6. 
68 Balakrishnan P, Katakam PK, Hegde AP. Familial hemiplegic migraine in a child with seizure disorder: clinical history is the key to diagnosis. BMJ Case Rep 2019;12:e228687.

69 Armand C, Masters-Israilov A, Lipton R. Migraine Mimics - Are we understanding migraines? 2019. Available: https://practicalneurology.com/articles/2019-may/ migraine-mimics

70 Raucci U, Della Vecchia N, Ossella C, et al. Management of childhood headache in the emergency department. review of the literature. Front Neurol 2019;10:886

71 Ohmura K, Suzuki Y, Saito Y, et al. Sporadic hemiplegic migraine presenting as acute encephalopathy. Brain Dev 2012;34:691-5.

72 Kerklaan JP, Lycklama á Nijeholt GJ, Wiggenraad RGJ, et al. Smart syndrome: a late reversible complication after radiation therapy for brain tumours. J Neurol 2011:258:1098-104.

73 Zheng Q, Yang L, Tan L-M, et al. Stroke-Like migraine attacks after radiation therapy syndrome. Chin Med J 2015;128:2097-101.

74 Black DF, Bartleson JD, Bell ML, et al. Smart: stroke-like migraine attacks afte radiation therapy. Cephalalgia 2006:26:1137-42

75 Kansagra S, Mikati MA, Vigevano F. Alternating hemiplegia of childhood. Handb Clin Neurol 2013:112:821-6.

76 Yilmaz A, Kaleagasi H, Dogu 0, et al. Abnormal MRI in a patient with 'headache with neurological deficits and CSF lymphocytosis (HaNDL)'. Cephalalgia 2010;30:615-9.

77 Raets I. Diffusion restriction in the splenium of the corpus callosum in a patient with the syndrome of transient headache with neurological deficits and CSF lymphocytosis (HaNDL): a challenge to the diagnostic criteria? Acta Neurol Belg 2012;112:67-9.

78 Montagna P, Gallassi R, Medori R, et al. Melas syndrome: characteristic migrainous and epileptic features and maternal transmission. Neurology 1988;38:751-4.

79 de Grauw TJ, Smit LM, Brockstedt M, et al. Acute hemiparesis as the presenting sign in a heterozygote for ornithine transcarbamylase deficiency. Neuropediatrics 1990;21:133-5.

80 Planche V, Chassin O, Leduc L, et al. Sturge-Weber syndrome with late onset hemiplegic migraine-like attacks and progressive unilateral cerebral atrophy. Cephalalgia 2014;34:73-7.

81 Karsan N, Palethorpe D, Rattanawong W, et al. Flunarizine in migraine-related headache prevention: results from 200 patients treated in the UK. Eur J Neurol 2018;25:811-7.

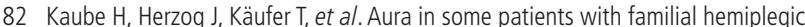
migraine can be stopped by intranasal ketamine. Neurology 2000;55:139-41.

83 Lai C-W, Ziegler DK, Lansky LL, et al. Hemiplegic migraine in childhood: diagnostic and therapeutic aspects, 1982.

84 Lampl C, Katsarava Z, Diener $\mathrm{H}-\mathrm{C}$, et al. Lamotrigine reduces migraine aura and migraine attacks in patients with migraine with aura. J Neurol Neurosurg Psychiatry 2005:76:1730-2.
85 Lastimosa AC. Treatment of sporadic hemiplegic migraine with calcium-channel blocker verapamil. Neurology 2003:61:721-2.

86 Razavi M, Razavi B, Fattal D, et al. Hemiplegic migraine induced by exertion. Arch Neurol 2000:57:1363-5.

87 Rozen TD. Treatment of a prolonged migrainous aura with intravenous furosemide. Neurology 2000;55:732-3.

88 Rozen TD. Aborting a prolonged migrainous aura with intravenous prochlorperazine and magnesium sulfate. Headache 2003:43:901-3.

89 Sánchez-Albisua I, Schöning $M$, Jurkat-Rott K, et al. Possible effect of corticoids on hemiplegic attacks in severe hemiplegic migraine. Pediatr Neurol 2013:49:286-8.

90 Tobita M, Hino M, Ichikawa N, et al. A case of hemiplegic migraine treated with flunarizine. Headache 1987:27:487-8.

91 Artto V, Nissilä M, Wessman M, et al. Treatment of hemiplegic migraine with triptans. Eur J Neurol 2007:14:1053-6.

92 Ueda K, Serajee F, Huq AM. Clinical Benefit of NMDA Receptor Antagonists in a Patient With ATP1A2 Gene Mutation. Pediatrics 2018;141:S390-4.

93 Young WB. The effect of Onabotulinum toxin on aura frequency and severity in patients with hemiplegic migraine - a comment. Headache 2019:59:110.

$94 \mathrm{Yu} \mathrm{W}$, Horowitz SH. Familial hemiplegic migraine and its abortive therapy with intravenous verapamil. Neurology 2001:57:1732-3.

$95 \mathrm{Yu} \mathrm{W}$, Horowitz SH. Treatment of sporadic hemiplegic migraine with calcium-channe blocker verapamil. Neurology 2003:60:120-1.

96 Athwal BS, Lennox GG, Elliott MA. Acetazolamide responsiveness in familial hemiplegic migraine. Ann Neurol 1996:40:820-1.

97 Camia F, Pisciotta L, Morana G, et al. Combined early treatment in hemiplegic attacks related to CACNA1A encephalopathy with brain oedema: blocking the cascade? Cephalalgia 2017;37:1202-6.

98 Centonze V, Brucoli C, Macinagrossa G, et al. Non-Familial hemiplegic migraine responsive to naloxone. Cephalalgia 1983;3:125-7.

99 Chen TY, Garza I, Dodick DW, et al. The effect of OnabotulinumtoxinA on aura frequency and severity in patients with hemiplegic migraine: case series of 11 patients. Headache 2018;58:973-85.

100 García Segarra N, Gautschi I, Mittaz-Crettol L, et al. Congenital ataxia and hemiplegic migraine with cerebral edema associated with a novel gain of function mutation in the calcium channel CACNA1A. J Neuro/ SCi 2014;342:69-78

101 Ho TW, Connor KM, Zhang Y, et al. Randomized controlled trial of the CGRP receptor antagonist telcagepant for migraine prevention. Neurology 2014;83:958-66.

102 Hsu DA, Stafstrom CE, Rowley HA, et al. Hemiplegic migraine: hyperperfusion and abortive therapy with intravenous verapamil. Brain Dev 2008;30:86-90.

103 Striano P, Zara F, Santorelli FM, et al. Topiramate-associated worsening symptoms in a patient with familial hemiplegic migraine. J Neurol Sci 2008;272:194-5. 